\title{
Advances in Cable Yarding: A Review of Recent Developments in Skyline Carriage Technology
}

\author{
Thomas Varch $^{1} \cdot$ Gernot Erber $^{1}$ (D) $\cdot$ Rien Visser $^{2}$ (D) $\cdot$ Raffaele Spinelli $^{3,4,5}$ (D) Hunter Harrill ${ }^{6} \cdot \operatorname{Karl~Stampfer~}^{1}$ D
}

Accepted: 12 October 2021 / Published online: 20 November 2021

(c) The Author(s) 2021

\begin{abstract}
Purpose of Review Carriages are an integral component of cable yarding systems that are used to harvest timber on steep terrain. They provide the mobility component by allowing a payload to be pulled along a skyline that spans a harvest setting, as opposed to a brute force pulling a load along a slope. While yarder machinery and cable yarding systems are extensively studied and reported, this paper provides a first detailed review of recent developments in carriage technology.

Recent Findings There has been significant development in carriage technology in the last decade. In addition to step changes in functionality, they are now also used as technology platforms. This includes integration of geospatial and camera technology to provide for higher levels of automation. There are clear regional drivers that have differentiated carriage development. The need for low mass, versatility, and energy efficiency has generated a demand for electric carriages in the central European market. A focus on safety has driven New Zealand designers to work almost exclusively grapple carriages that no longer need choker setters on the ground being exposed to danger. North American developments include carriages capable of larger payloads to increase productivity and off-set high operation cost.

Summary Carriages have developed over time to become complex systems and provide additional capabilities instead of just providing a mobility and transfer mechanism within the yarding systems. By integrating new technologies that provide for greater efficiency and/or automation, carriage developments will help cable yarding systems remain cost-competitive, with high safety standard and environmentally sound.
\end{abstract}

Keywords Steep terrain harvesting $\cdot$ Cable logging $\cdot$ Carriage $\cdot$ Energy recuperation $\cdot$ Grapple carriage $\cdot$ Horizontal yarding

This article is part of the Topical Collection on Forest Engineering

Gernot Erber

gernot.erber@boku.ac.at

Thomas Varch

thomas.varch@boku.ac.at

Rien Visser

rien.visser@canterbury.ac.nz

Raffaele Spinelli

raffaele.spinelli@ibe.cnr.it

Hunter Harrill

hh19@humboldt.edu

Karl Stampfer

karl.stampfer@boku.ac.at

1 Department of Forest and Soil Sciences, Institute of Forest Engineering, University of Natural Resources and Life Sciences Vienna, Peter Jordan Strasse 82, 1190 Vienna, Austria
2 School of Forestry, University of Canterbury, Private Bag 4800, 8140 Christchurch, New Zealand

3 CNR-IBE Consiglio Nazionale Delle Ricerche-Istituto Per La BioEconomia, Via Madonna del Piano 10, Sesto Fiorentino 50019 Florence, Italy

4 Forest Industries Research Centre (FIRC), University of the Sunshine Coast, Locked Bag 4, Maroochydore, DC, QLD 4558, Australia

5 Department of Forest Operations, Skogforsk, Dag Hammarskjölds väg 36 A, Uppsala Science Park 5183, Uppsala, Sweden

6 Department of Forestry and Wildland Resources, Humboldt State University, 1 Harpst Street, Arcata, CA 95521, USA 


\section{Introduction}

In its wider sense, a carriage is a wheeled device capable of moving a load on a pre-determined path. The term is generally applied to railway cars or to horse-drawn coaches [1], but it is not exclusive to them. The same term is applied to cable yarding, with the main difference that the path is a cable and not a track, and the load is suspended under the carriage and not on top of the carriage itself [2] (Fig. 1). Using this definition, the first implication is that carriages are specifically associated with skyline yarding systems [3], while in all other cases, a common term is "butt rigging"— not a carriage proper [4].

Skyline carriages can be described and classified in several ways. Essentially, a carriage performs three functions: it moves, it stops, and it provides the opportunity to reach and attach a load. Therefore, it can be described based on how it moves, how it stops, and how it reaches its load and connects to it (Fig. 2). The carriage's functions are also represented by the work elements into which a yarding cycle is commonly divided in work studies: outhaul, hook-up or loading, inhaul, and unhook or unloading [6].

Carriage movement along the skyline and towards the yarder is achieved using a cable called the mainline. Carriage movement back out to the loading area along the skyline may be solely from the assistance of gravity (gravity carriages) or be independent of it (non-gravity or all-terrain carriages). In the latter case, movement is obtained by an additional winch and cable called the haulback line. As their name implies, all-terrain carriages are more versatile than gravity carriages but generally more complex and expensive.

An exception to the mainline/haulback system is the selfpropelled carriage, where a built-in motorized drive system pulls the carriage along the skyline. As to the type of track (skyline) the carriage can move along, the main distinction
Fig. 1 Basic diagram of a skyline cable yarding system in an uphill (A) and a downhill (B) yarding setting, showing (a) yarder, (b) skyline, (c) anchors, (d) carriage with chokers connecting to the load, (e) mainline, and (f) haulback line (after [5], adapted)

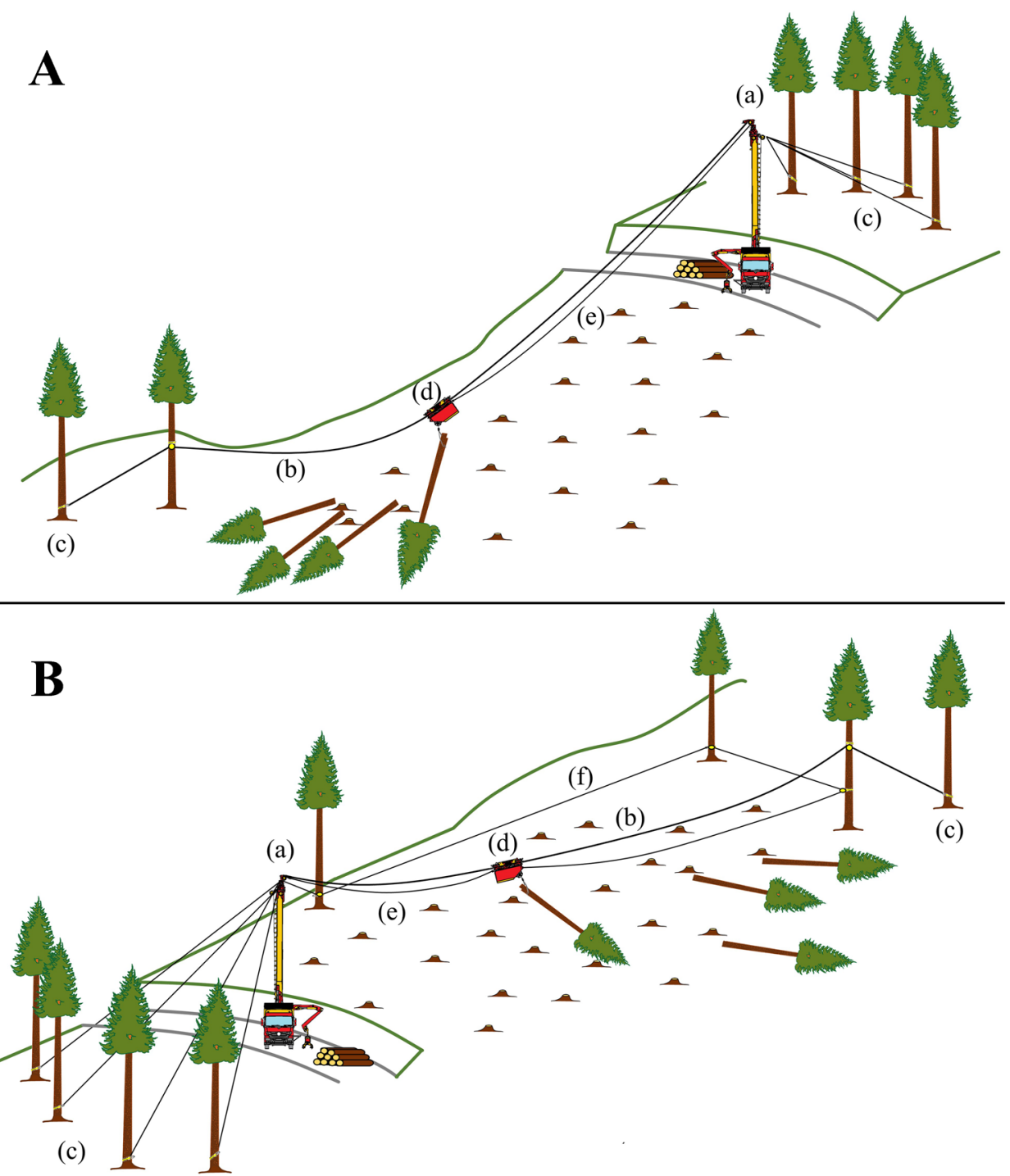



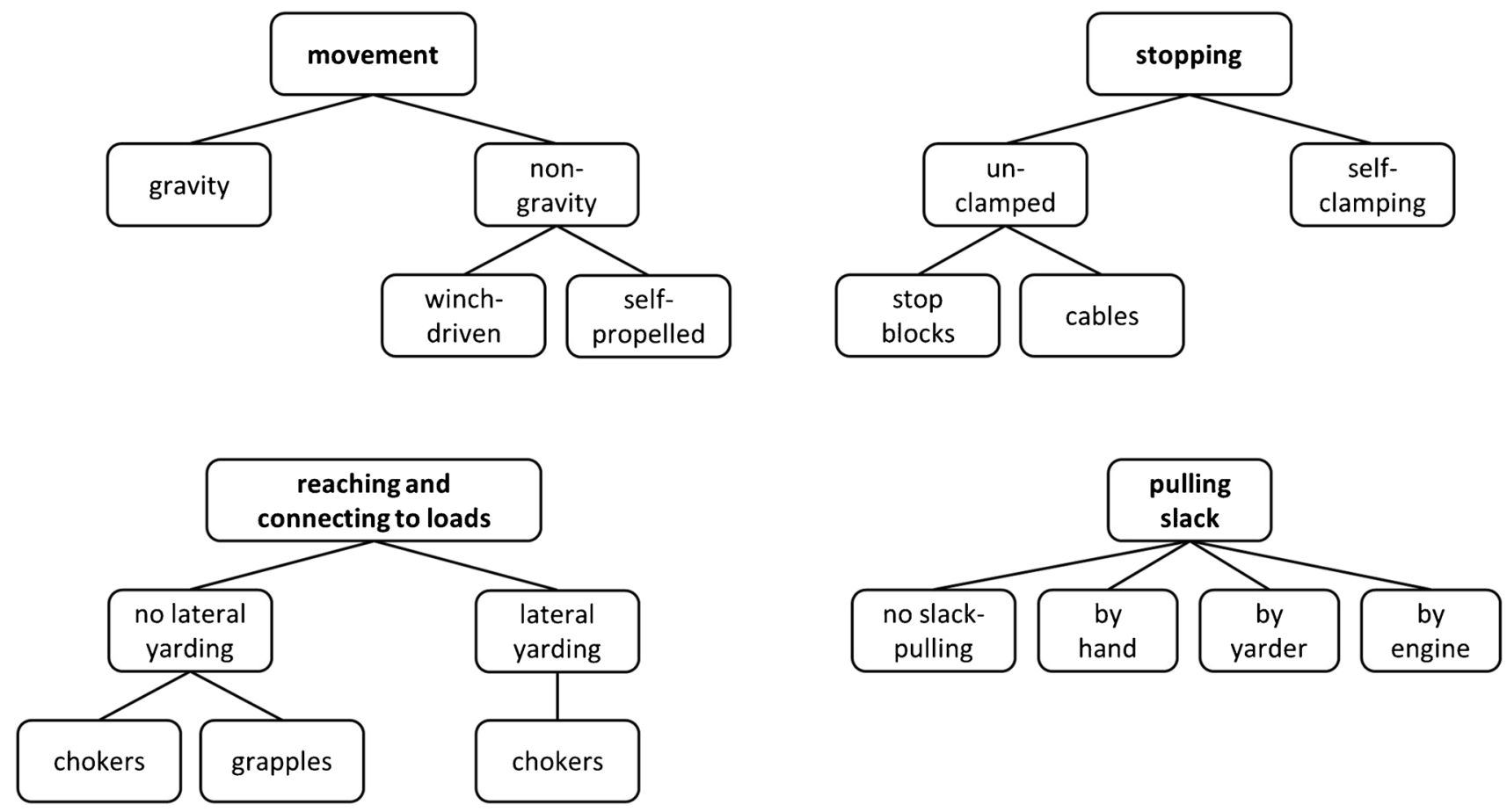

Fig. 2 Classification of carriages by way of movement, stopping, reaching and connecting to loads and pulling slack

is between single-span and multi-span carriages. The latter have an open structure and can pass over intermediate supports, while the former have an enclosed structure and must stop in front of a support [7].

Regarding the carriage stopping and remaining in place at the loading points and the landing, the simplest option is to brake the cable that prevents gravity from moving the carriage away (unclamped carriages). A carriage can also hold fast to the skyline by a built-in clamp (self-clamping carriages) or by a separate stop placed along the skyline.

When it comes to reaching loads, the simplest carriages only allow to retrieve those loads that are located directly below the skyline. This usually requires the skyline to be lowered with the carriage and limits efficient deployment to clear-cut operations [8]. This is because the weight of the skyline, carriage, and other rigging equipment is too heavy for the forest worker on the ground to move. A carriage that facilitates the extraction of material further away from the carriage is referred to as a "slack-pulling" carriage—that is, a carriage capable of lateral yarding.

Lateral yarding capacity allows for a wider spacing of skyline corridors and grants the benefit of less frequent line shifts [9]. Carriages with lateral yarding capacity can be used in any type of silvicultural treatment and are particularly suited to operations where residual trees need to be protected from yarding damage $[10,11]$. Non-lateral yarding carriages can connect to their loads through chokers or grapples. All lateral yarding carriages use chokers as it is difficult to move a heavy full-size grapple any distance from directly under the skyline.

Lateral yarding is achieved by a segment of rope referred to as the "dropline," which can be the same mainline or haulback line or a separate line being spooled out from a drum mounted in the carriage. Under specific conditions, a dropline can be paid out by gravity, but it is far more common on modern carriages to be supported by some mechanical device. Slack can be pulled mechanically by the yarder through a dedicated line or by a motor mounted in the carriage in the case of motorized slack-pulling carriages. If the dropline is contained in a separate built-in motorized winch, then one will talk about a motorized dropline carriage [8]. Finally, payload capacity is used for discriminating between light, medium or heavy carriages [12]. Operators of cable yarders can choose from a very wide range of types and models, all of which can be described through the abovementioned attributes.

Modern-day skyline carriages are the result of a long evolution that begun shortly after their first documented appearance in 1886 [13]. Within very few years (1891), slack-pulling was introduced [13], which has been refined through increasingly sophisticated and functional trigger mechanisms and powering devices [14]. Adoption of radio control in the 1960s [15] enabled alternating control of the carriage by the yarder operator and the choker setter [14]. Further, radio control was instrumental in the development of grapple carriages in 1970s that allowed loads to be picked 
up without a worker on the slope and thus made it possible to cope with workforce shortages [15]. Implementation of automation of carriage movement in the 1980s and 1990s constituted a further major step in carriage technology development. It enabled automated movement between the loading points and the landing stations, where the carriage would stop automatically and wait for further commands. Thereby, the yarder operator and the choker setter were spared from controlling the carriage during travel and could engage in other more productive work tasks [14].

Carriage technology has evolved substantially over the last decade in response to recent challenges in steep terrain harvesting. These have included labor shortage, stricter safety standards, rising fuel cost, and increasing environmental restrictions $[16 \bullet, 17 \bullet \bullet, 18-20]$. Therefore, past reviews of skyline carriage technology $[8,21]$ may no longer reflect the current state of the art. Glimpses of new carriage technology are offered individually by ad hoc papers that often consider carriage innovation within the context of the cable yarding systems rather than focusing on carriage specifics. Lack of focus and fragmentation of results contribute to partially obscure the considerable progress achieved in the specific field of skyline carriage technology, despite recent and notable innovation.

This paper aims to highlight recent progress in carriage technology and illustrate how some skyline carriage manufacturers in Europe, New Zealand, the Western United States, and Canada have reacted to the new demands for better fuel efficiency, improved environmental performance (e.g., lower fuel consumption, extraction on sensitive soils), and increased worker safety.

\section{Methodology}

To this end, scientific literature databases (Web of Science, Scopus, Google Scholar) were searched for peer-reviewed publications by combining the mandatory search term "carriage" (in title, abstract, or keywords) with variations and combinations of "logging," "cable," and "yarding." The search was limited to studies published over the last $2 \mathrm{dec}$ ades, with a preference for those from the last 10 years. Results were then screened for studies that specifically addressed the carriage and its effects. In addition, other online literature databases (e.g., Forest Growers Research Ltd. or the US Forest Service's Treesearch) and practical journals (e.g., the Austrian "Forstzeitung," the German "Forstmaschinenprofi") were scoured for materials on the subject. Finally, the search was complemented by the authors' personal collections of scientific articles, books, and reports. From the collected materials, trends in skyline carriage technology over the last 10 to 20 years were identified, and three major ones were selected by the author group for presentation in this publication: energy-recuperating slack-pulling carriages, double-hitch carriages, and grapple carriages. In addition, manufacturers of these carriages were contacted for technical details on the carriages, which were merged into overviews of the carriage models currently available on the market.

\section{Results}

\section{Better Fuel Efficiency: Energy-Recuperating Slack-Pulling Carriages}

Over the last 2 decades, slack-pulling carriages have reached a high level of maturity [14]. Change and improvements to the designs were mostly incremental in nature, e.g., replacement of engines to comply with emission regulations. The introduction of energy recuperation systems by several European manufacturers was an exception to this. The rationale was to increase the operational and ecological efficiency of cable yarding by recuperating some of the energy that needs to be dissipated when moving cables, carriage, and load (e.g., applying braking forces to the drums). This can then be used to replace power supply from fossil fuels. Fossil fuel consumption ranks among the top three entrepreneur concerns $[17 \bullet \bullet, 20]$, and fuel cost represents up to $20 \%$ of total system cost in cable yarding [22]. With respect to carriages, developments specifically aimed at replacing combustion engine drives for slack-pulling devices by drives powered by recuperated energy.

In mechanical engineering, "recuperation" refers to processes by which kinetic or thermal energy can be recovered, usually in converted form, and stored in dedicated storage media. Converted forms are electrical or hydraulic energies, and accumulators, capacitors, and hydro-pneumatic pressure accumulators can be used for storage [23]. The first recuperation systems were developed for racing cars and became operational in 1996. These systems used a generator to recuperate braking energy, which otherwise would have had to be dissipated as heat through brake discs. Recuperated energy was then used for boosting acceleration [24]. Today, the same technology is used in passenger cars to increase fuel efficiency by temporally replacing the combustion engine drive by an electric one [25-27].

Early examples for the use of energy recuperation technology in skyline carriages include the BK-25 E carriage (Gantner, Sulz, Austria) and the HASK 3500 carriage, the latter designed by Stuefer (Langkampfen, Austria) [14]. In 2002, Greifenberg constructed a fully electric carriage ( $\mathrm{Ht}$ 30 ) that was powered by energy recuperated during movement of the carriage. However, technical problems caused by the lesser sophistication of the electro-hydraulic components available at the time resulted in the electrical recuperation 
system being replaced by a hydro-pneumatic one (mail from Greifenberg D, Greifenberg Teleferiche SAS, Mar 2021). In the 2010s, other manufacturers followed: Franz Hochleitner with the Bergwald 5000 Hybrid and Prysis with the CableCar 30 in 2012; Koller, who had acquired Stuefer in 2007, with the ESK 2.0 in 2015; and Konrad with the E-Liner [28-32]. In 2018, Schilter presented the SE 4000 [32]. In the same year, Mayr-Melnhof launched the Sherpa UE series [32] and then also acquired Prysis in 2020 [29]. As of April 2021, 6 manufacturers offer 13 different types of energyrecuperating carriages (Table 1 ).

Energy for powering slack-pulling is recuperated either during movement of the carriage, during loading, or both. In the first case, this is achieved by radial piston pumps or generators connected to the skyline sheaves. Such devices are currently included in only two carriages, being the MayrMelnhof PRYSIS H3 and Greifenberg Ht 30. In most cases, energy is recuperated during the movement of the load and more precisely during lateral yarding (Table 1 ). To this end, the line to which the load is attached is run over a traction sheave inside the carriage, and the sheave is connected to a combination of electrical generator and engine. Thus, when the line is pulled in during lateral yarding, the device's generator functionality is used for recuperating energy, while its engine functionality is used for slack-pulling during the subsequent cycle. In addition to lateral yarding, the Schilter and Koller carriages recuperate energy during lowering of the load ([41], conversation with Gschwenter C, Koller Forsttechnik GmbH, Mar 2021). For Konrad carriages, this feature is only available as an option [35]. The Koller ECKO BOOST carriage offers a further feature: during lateral yarding, energy recuperation can be suspended, and the slackpulling device can be used to enhance lateral yarding pull by up to $20 \%$, if required [33]. While all other energy-recuperating carriages are independent designs, existing MayrMelnhof Sherpa carriages can be retrofitted with the energy recuperation and energy storage unit to become Sherpa UE types [37].

Accumulators $\left(n^{\circ} 5\right)$ and supercapacitors $\left(n^{\circ} 6\right)$ are the most frequently used type of energy storage media in energyrecuperating carriages, while hydraulic accumulators $\left(\mathrm{n}^{\circ} 2\right)$ are less popular (Table 1). Accumulators are rechargeable energy sources that differ in structure, design, material, and chemical components and consist of at least two cells, usually arranged in series [42, 43]. Carriage designs where accumulators (usually lithium-ion types) are used cannot be operated self-sufficiently. In this case, energy recuperation extends operating time, but recharging of the accumulators by external sources is required after one to two days of operation (conversation with Herzog J, Franz Hochleitner $\mathrm{GmbH}$, Apr 2021, mail from Vilsmeier A, Mayr-Melnhof Forsttechnik GmbH, Apr 2021). On the contrary, capacitors

Table 1 Energy-recuperating carriages by manufacturer, energy recuperation system, payload, mass, and line payout force

\begin{tabular}{|c|c|c|c|c|c|c|}
\hline Manufacturer & Carriage model & $\begin{array}{l}\text { Energy recuperation } \\
\text { system/recuperation } \\
\text { during }\end{array}$ & $\begin{array}{l}\text { Recuperated energy } \\
\text { stored in }\end{array}$ & Payload & Carriage mass & Line payout force \\
\hline \multirow{3}{*}{$\begin{array}{l}\text { Koller Forsttechnik } \\
\text { GmbH (Schwoich } \\
\text { bei Kufstein, Austria) } \\
{[33,34]}\end{array}$} & ECKO UP & \multirow{3}{*}{$\begin{array}{l}\text { Electrical generator/ } \\
\text { lateral yarding (in), } \\
\text { lowering load }\end{array}$} & \multirow[t]{3}{*}{ Supercapacitor } & $14.7 \mathrm{kN}$ & $4.9 \mathrm{kN}$ & \multirow[t]{3}{*}{ Up to $>9.8 \mathrm{kN}$} \\
\hline & ECKO FLEX & & & $19.6 \mathrm{kN}$ & $5.9 \mathrm{kN}$ & \\
\hline & ECKO BOOST & & & $39.2 \mathrm{kN}$ & $8.7 \mathrm{kN}$ & \\
\hline \multirow{2}{*}{$\begin{array}{l}\text { Konrad Forsttechnik } \\
\text { GmbH (Preitenegg, } \\
\text { Austria) }[35,36]\end{array}$} & E-Liner 3to & \multirow{2}{*}{$\begin{array}{l}\text { Electrical generator/ } \\
\text { lateral yarding (in) }\end{array}$} & \multirow[t]{2}{*}{ Supercapacitor } & $39.2 \mathrm{kN}$ & $5.8 \mathrm{kN}$ & Up to $2.5 \mathrm{kN}$ \\
\hline & E-Liner 5to & & & $49.0 \mathrm{kN}$ & $7.4 \mathrm{kN}$ & $\mathrm{Up}$ to $3.4 \mathrm{kN}$ \\
\hline \multirow{4}{*}{$\begin{array}{l}\text { Mayr-Melnhof } \\
\text { Forsttechnik GmbH } \\
\text { (Frohnleiten, Austria) } \\
{[37,38]}\end{array}$} & SHERPA UE 3 & \multirow{3}{*}{$\begin{array}{l}\text { Electrical generator/ } \\
\text { lateral yarding (in) }\end{array}$} & \multirow[t]{3}{*}{ Accumulator } & $29.4 \mathrm{kN}$ & $4.8 \mathrm{kN}$ & \\
\hline & SHERPA UE 4 & & & $39.2 \mathrm{kN}$ & $5.7 \mathrm{kN}$ & \\
\hline & SHERPA UE 4 XL & & & $39.2 \mathrm{kN}$ & $7.6 \mathrm{kN}$ & \\
\hline & PRYSIS H3 & $\begin{array}{l}\text { Radial piston pump/ } \\
\text { lateral yarding (in) }\end{array}$ & Hydraulic accumulator & $29.4 \mathrm{kN}$ & $5.7 \mathrm{kN}$ & $1.6 \mathrm{kN}$ \\
\hline \multirow{2}{*}{$\begin{array}{l}\text { Franz Hochleitner } \\
\text { GmbH (Bodman/ } \\
\text { Bodensee, Germany) } \\
{[39]}\end{array}$} & Bergwald 3500 Hybrid & \multirow{2}{*}{$\begin{array}{l}\text { Electrical generator/ } \\
\text { lateral yarding (in) }\end{array}$} & \multirow[t]{2}{*}{ Accumulator } & $34.3 \mathrm{kN}$ & $4.4 \mathrm{kN}$ & Up to $3.9 \mathrm{kN}$ \\
\hline & $\begin{array}{l}\text { Bergwald } 5000 \text { Hybrid } \\
\text { Power Plus }\end{array}$ & & & $49.0 \mathrm{kN}$ & $6.8 \mathrm{kN}$ & Up to $6.4 \mathrm{kN}$ \\
\hline $\begin{array}{l}\text { Greifenberg Telefer- } \\
\text { iche SAS (Terzolas, } \\
\text { Italy) [40] }\end{array}$ & Ht 30 & $\begin{array}{l}\text { Radial piston pump/ } \\
\text { inhaul }\end{array}$ & Hydraulic accumulator & $31.4 \mathrm{kN}$ & $2.9 \mathrm{kN}$ & $0.7 \mathrm{kN}(30 \mathrm{~s})$ \\
\hline $\begin{array}{l}\text { Schilter Seilbahn- und } \\
\text { Metallbau GmbH } \\
\text { (Erstfeld, Switzer- } \\
\text { land) [41] }\end{array}$ & SE 4000 & $\begin{array}{l}\text { Electrical generator/ } \\
\text { inhaul, lateral yard- } \\
\text { ing (in), lowering } \\
\text { load }\end{array}$ & Supercapacitor & $39.2 \mathrm{kN}$ & $7.11 \mathrm{kN}$ & $\mathrm{Up}$ to $>9.8 \mathrm{kN}$ \\
\hline
\end{tabular}


and hydraulic accumulators allow self-sufficient operation without any need for periodical recharging by an external source. Capacitors usually consist of two electrodes, separated by insulation. Plate, cylindrical, block, and spherical designs are available, among which the first two types are the most common $[44,45]$. In carriages, "electro-chemical double-layer capacitors" (ECDLs) are used. Their advantages over accumulators are a much higher number of possible charge and discharge cycles, superior energy density $[46,47]$, and a much higher charge current, which allows to charge them within very short periods [42]. For example, in the Konrad E-Liner 5to, two sets of ECDLs are used, which can be charged at currents of up to $1800 \mathrm{~A}$ and a charging power of $3 \mathrm{~kW}$ (conversation with Konrad M, Konrad Forsttechnik GmbH, Feb 2021). In case of accidental discharge, the ECDLs can be recharged by backup accumulators [35] or by manual pulling out the line and pulling it in with the yarder (conversation with Gschwenter C, Koller Forsttechnik GmbH, Mar 2021). Hydraulic accumulators can be divided into mechanical and hydro-pneumatic systems [48, 49]. Mechanic types store pressure energy depending on the potential energy of the weight or spring load, while hydropneumatic systems are filled with a gas, usually nitrogen, at a predetermined pressure [50]. The advantages of these systems are their very compact design, low susceptibility to failure, low fire risk, and an efficiency almost comparable to ECDLs [51]. Regardless of storage media type, all carriages are equipped with small accumulators, which power other functions (e.g., radio control, clamps) and are recharged by recuperation (usually through generators connected to skyline sheaves).

Most energy-recuperating slack-pulling carriages are designed for all-terrain operation. However, operability of the slack-pulling devices is limited in downhill yarding settings. Especially when the carriage is stationed far away from the yarder, most slack-pulling devices are not powerful enough to overcome the weight of the mainline and allow efficient slack-pulling (Table 1). The Franz Hochleitner Bergwald, Koller ECKO Flex and ECKO Boost and the Schilter SE 4000 carriages are exceptions to this: these carriages provide maximum line payout forces between 6.4 and over $9.8 \mathrm{kN}$, which are sufficient to allow slack-pulling in downhill yarding [34, 41], even when the carriage is $800 \mathrm{~m}$ away from the yarder, in the case of Bergwald models (conversation with Herzog J, Franz Hochleitner GmbH, Apr 2021). A different solution to this problem was developed by Mayr-Melnhof, who combined energy recuperation and electrical slack-pulling in uphill yarding direction with mechanical slack-pulling in downhill direction for their Sherpa UE carriages [37].

Employment of energy-recuperating slack-pulling carriages is expected to reduce fuel consumption compared to operations with standard, combustion-engine carriages.
However, for their novelty, scientific studies on energyrecuperating carriages are rare. In the first study of its kind, an energy-recuperating carriage with an electric slack-pulling drive was compared to a standard carriage with a diesel engine slack-pulling drive during uphill yarding with a

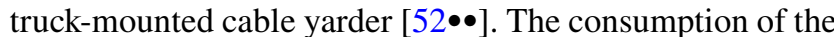
diesel engine carriage equalled $9.0 \%$ of the total and fuel consumption per cycle, per $\mathrm{m}^{3}$, and per $\mathrm{h}$ was significantly higher than with the energy-recuperating. On the other hand, yarder consumption did not differ between the treatments, which confirmed that the impact was limited to the carriage. About two-thirds of variation in fuel consumption could be explained by average tree volume, yarding distance, lateral yarding distance, and an interaction between average tree volume and carriage type. The latter implied that fuel consumption was lower with the energy-recuperating carriage, but that this effect was capped by a break-even average tree volume, which decreased with increasing yarding distance. The authors concluded that future studies would have to investigate this effect more closely, as well as the use of the recuperating carriage over longer yarding distances. Further, to fully reveal the carriage's effect on fuel consumption, winch and processor unit fuel consumptions would have to be separated, as the latter may be independent of the carriage type but interacts with the previous yarding cycle's load volume and thus blurs the carriage's effect.

The potential for larger payloads when using lower-mass energy-recuperating carriages was recognized early [14]. A quick comparison of payload capacity vs. carriage mass suggests that energy-recuperating slack-pulling carriages are lighter than their combustion engine counterparts. This may be primarily attributed to the lighter and smaller design of electric engines and energy storage media. However, the assumption of higher payloads and, accordingly, higher productivity is not supported by the results of the first study on the subject [52••]. Neither load volume, nor productivity differed significantly from working with the diesel engine counterpart. In this respect, the authors pointed out that payload utilization is also constrained by the availability of trees within reaching distance, tree volume, and the availability of sufficient chokers to hook them all. A further study [53] investigated the productivity of a Koller ESK 2.0 (precursor of the Koller ECKO series) during uphill yarding in a thinning and a final felling operation and found that productivity did not differ from that reported in previous studies of nonrecuperating carriages.

Finally, energy-recuperating carriages offer further advantages: electrical engines are less maintenance intensive and prone to damage than combustion engines, which

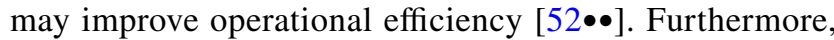
the absence of fuel in the carriage makes electrical models particularly suited to sensitive areas where fuel spills would have the most serious consequences. Finally, 
energy-recuperating carriages are considerably quieter in operation, which is beneficial in term of environmental (e.g., disturbance of wildlife by operations) and for some aspects related to operator safety (increased awareness of other noises, otherwise masked by diesel engine noise).

\section{Improved Environmental Performance: Double-Hitch Carriages}

Normally, a skyline carriage will hold its load attached at one point, so that the load is hanging under the carriage. That is adequate under most circumstances, especially if the wood is yarded after processing in the form of logs, which are relatively short. However, the increasing popularity of processors and the development of a lucrative market for forest biomass have justified a widespread preference for whole-tree extraction, which is the best way to effectively profit from the combined benefits of mechanized processing and residue recovery [54]. As a result, yarders and carriages are now transporting much longer loads, which require higher ground clearance and have a greater tendency to swing during movement. This problem is particularly serious in the case of downhill yarding, when the load can hit the ground or suddenly drop ahead of the carriage, with all associated shock-loading issues. One obvious solution is to tie whole trees at two points and hold them horizontally, to increase ground clearance and limit swinging. In fact, this technique is commonly practiced in civil engineering, where cableways are used to provide access to locations that cannot be reached by other means, e.g., when building bridges, dams, or pipelines.

Horizontal, full-suspension yarding is not new to forestry, and it is documented in the scientific literature since the late 1960s [55, 56]. Early double-hitch carriages are categorized as "load beam" carriages in the seminal FAO publication dedicated to yarding [7]. The problem with these older versions was that they were not suited to lateral yarding and could generally reach only those loads that were placed directly under the skyline. In contrast, the new double-hitch carriages appeared in recent years have both full suspension and lateral yarding capabilities. That is made possible by the introduction of hydraulically powered motorized dropline winches, which were not readily available earlier on. In fact, efficient lateral yarding capability requires that the two hoist lines in the double-hitch carriage can operate independently of each other through individual winches. That is easily achieved if the carriage is equipped with an engine and a hydrostatic transmission that can power two independent hydraulic motors.

The new double-hitch skyline carriages appeared in the European Alps several years ago and normally consist of a conventional single-hitch carriage coupled with a so-called trailer-i.e., a detachable secondary carriage fitted with an additional winch for the second dropline. Therefore, all double-hitch carriages only incur the additional cost of the addon trailer and can be easily reconverted to single-hitch mode when horizontal full suspension yarding is not necessary. These carriages have enjoyed growing popularity ever since their first appearance on the market, although they remain a niche product. Presently, they are available from three manufacturers: Franz Hochleitner GmbH (Bodman/Bodensee, Germany), Seik GmbH (Truden, Italy), and Wyssen Seilbahnen AG (Reichenbach, Switzerland). Early studies indicate that shifting from a single-hitch to a double-hitch carriage results in a reduction of skyline cyclic loading (oscillation) between 30 and 50\% [57••]. On the other hand, mean tensile force in the skyline may increase significantly for the same payload, since a double-hitch carriage is inevitably heavier than a single-hitch carriage in the same payload size class. Fortunately, the quoted study also confirms that in no case did tensile force in the skyline exceed the endurance limit and that shock-loading was smaller and less frequent under the double-hitch configuration, possibly due to the lower pulling force of the hydraulic dropline winch. Being fitted with two independent winches, the double-hitch carriage can accumulate slightly larger loads $(+12 \%)$ than its single-hitch equivalent; yet loading takes a longer time $(+14 \%)$, which can be offset by the increased travel speed $(+15 \%)$ only if extraction distance is long enough. Over yarding distances below $300 \mathrm{~m}$, horizontal full suspension yarding incurred an additional cost around 15\% [58•]. Under these conditions, deployment of a double-hitch carriage may be justified mainly by a need for increased ground clearance, with gains estimated in the range of about $10 \mathrm{~m}[57 \bullet \bullet]$. This advantage can be crucial with specific terrain profiles and may allow shot-gunning loads downhill where that would not be feasible otherwise. For that reason, double-hitch carriages could represent an especially valuable addition to conventional sled-winch operations, which are still very popular in the Alpine area [59]. Even where full suspension would not be indispensable to technical operation, minimum ground contact would have the advantages of lower soil disturbance and wood contamination - the latter being especially valuable in the case of biomass recovery [60]. For that reason, doublehitch horizontal suspension could be considered crucial to extending cable yarding to sensitive sites on flat terrain [18].

\section{Increased Worker Safety: Grapple Carriages}

The last decade constituted a period of considerable change in timber harvesting in steep terrain in New Zealand and the Pacific Northwest. As outlined in two recent reviews $[16 \bullet, 17 \bullet \bullet$, there were multiple drivers for change: firstly, a stronger focus on occupational safety to maintain social license to operate; secondly, a need to become more efficient to sustain and increase productivity 
levels, while average tree sizes decreased due to a shift from pruned, large tree stands to structural, smaller tree stands [61]; and thirdly, the industry had to cope with a shortage of skilled labor and low attraction to new entrants [62].

In 2010, a 7-year initiative, the "Steepland Harvesting Programme," was established in New Zealand as a cooperation between the Ministry of Primary Production and Forest Growers Research Ltd. (Rotorua, New Zealand), with the goal to realize substantial safety, productivity, and cost efficiency gains through the development and implementation of innovative mechanized and remote-controlled harvesting technologies. The guiding vision was "no worker on the slope, no hand on the chainsaw" [63]. With respect to cable yarding, removing workers from the slope meant to abandon rigging configurations involving manual tasks (e.g., choker setting) or practices that required workers to station on the cutover (e.g., spotters). In Canada, a 6-year program (Steep Slope Initiative) with similar goals was initiated by FP Innovations in 2015 [64].

By the early 2010's, the first winch-assisted, fully mechanized harvesting systems were available that allowed mechanizing felling, processing, and extraction on steep terrain previously inaccessible to harvesting machines, and the immediate success of these machines spurred further development, production, and distribution around the globe [65•]. Their employment does not only remove workers from the hazards of motor-manual felling on steep slopes but improves the conditions for extraction by cable yarding through superior load presentation in bunches. Better load presentation increases yarding productivity and can be further enhanced by feeding tree bunches into the grapple carriage with another machine (e.g., an excavator) [66-68]. Through mechanized bunching, loads can be presented directly on the yarding corridor, thus compensating for the largely limited lateral yarding capability of grapple carriages, a limitation which has not been overcome yet. However, at least one concept involving two laterally extendable grapples has been presented and studied during the past decade $[69,70]$.

In the past, most of the grapples in use were of the mechanical type, which means they were actuated using another line coming from the yarder (closing line). While mechanical grapples are relatively light, robust, and cheap, they must be operated in running skyline systems, which require a three-drum (mainline, haulback, and closing line) yarder with an interlock system. Such systems are mostly found on swing yarders that are generally heavier and more expensive than other yarder types [71]. Mechanical grapples require great skill in handling, particularly regarding rotation, which is usually actuated by either movement of the swing yarder crane or by contact of the grapple with the ground [72].
Extension of grapple yarding to tower yarders, usually equipped with two drums (mainline and haulback line for live skyline systems), required a different approach for opening, closing, and rotating the grapple. That has led to the development of remote-controlled grapple carriages, with integrated drives for some or all grapple functions. Neither remote control of grapple carriages nor integrated drives constitute novelties in themselves; repeated attempts are documented since as early as the 1960s [15]. However, over the last decade, the designs have been continuously improved and refined, particularly regarding grapple function drives and grapple mass, e.g., a drop from 21.1 to 12.3 $\mathrm{kN}$ for the Falcon Forestry Claw between the original 2150 to the actual 1250 model, while increasing payload and grapple opening width at the same time [64]. Several new manufacturers have entered the market, and many new models have been developed (Table 2). These may be distinguished into "pure" grapple carriages and combined types, whereby the later usually comprise of slack-pulling carriages, for which detachable grapple units are available [73-76]. In most of the carriages, diesel engines act as power source for the hydraulic systems that actuate grapple opening, closing, and rotation. Engine power, maximum grapple opening, and carriage mass of current models ranges from 6 to $60 \mathrm{~kW}$, from 1.30 to $4.00 \mathrm{~m}$, and from 7.9 to $39.2 \mathrm{kN}$, respectively. Some of these carriages employ different drive concepts: The Eagle and Alpine carriage's grapple opening and rotation functions are hydraulically powered, while closing of the grapple is actuated by the mainline. The hydraulic energy is stored in accumulators, which are recharged during carriage travel by a pump connected to one of the haulback/skyline sheaves. Therefore, no internal engine is required, which is advantageous regarding carriage mass, maintenance, and cost of operation [76, 77].

Remote control and integrated drives greatly facilitate the extension of grapple carriage use to tower yarders and substantially improve their agility and controllability. However, they do not solve some characteristic issues of grapple yarding, namely: reaching loads that are not clearly visible for the yarder operator because they are simply too far away or hidden behind some terrain feature. Personnel can be stationed on the cutover-so-called "spotters"- who guide the yarder operator into the right position by audio signals or handheld radio. Though considered an effective practice, this approach fails to achieve the goals of completely removing workers from the slope. The obvious solution is to replace the spotter with a camera. Already in 1983, tests were conducted by placing a video camera on the cutover and connecting it to a display in the yarder cab, thus providing the yarder operator with a clear view of areas otherwise invisible to him [85]. A more advanced variation of this system, the CutoverCam, has been developed as part of the Steepland Harvesting Programme in New Zealand [63, 86], and it is 


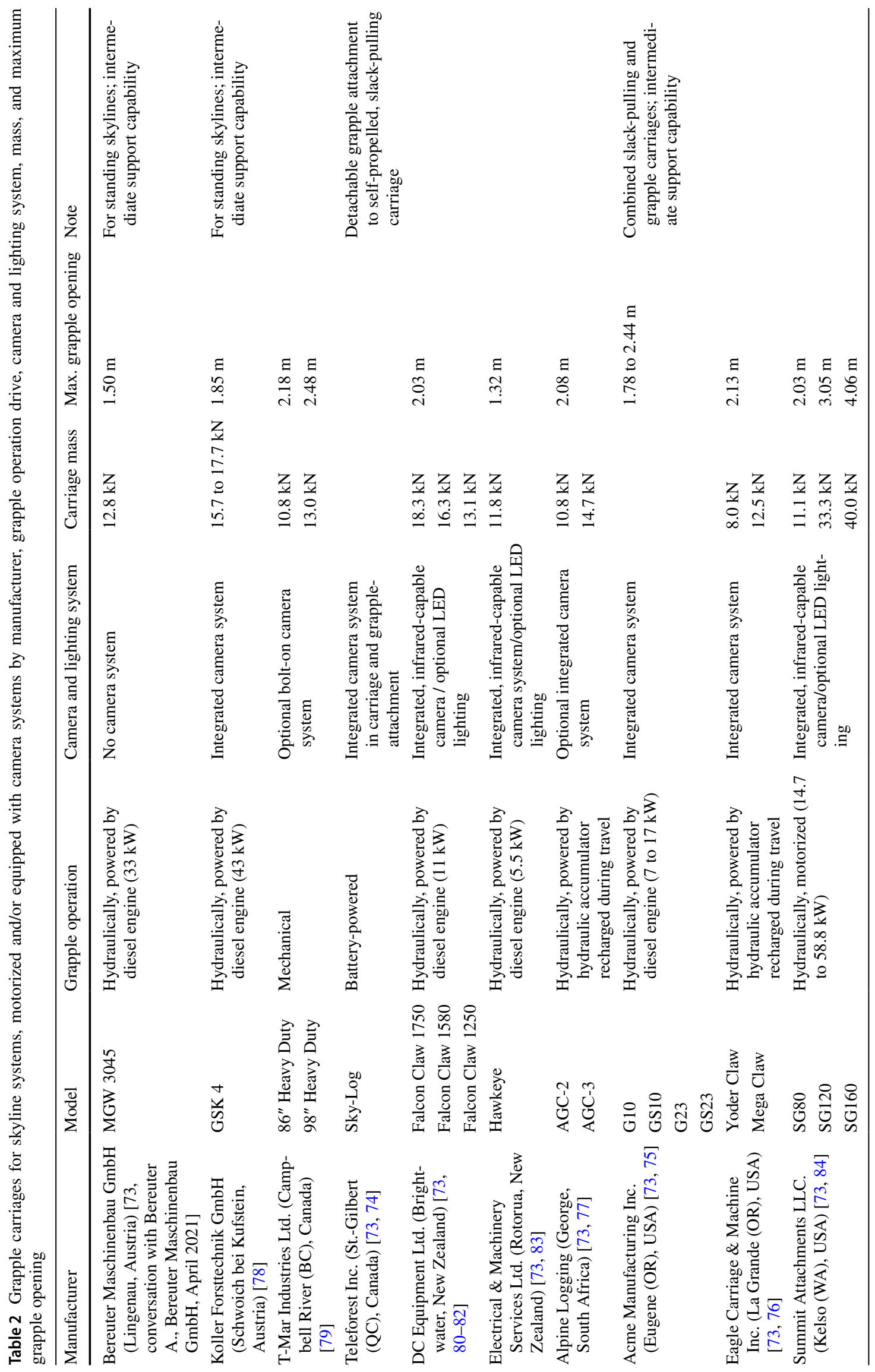


now commercialized by Applied Teleoperation Ltd. (Rotorua, New Zealand). This portable camera system is remote controlled by the yarder operator (pan, tilt and zoom) and can be set up anywhere on the cutover. An investigation of the CutoverCam's effect on productivity found that cycle times with the CutoverCam in out-of-line-of-sight areas did not differ significantly from line-of-sight operation, while they were significantly longer compared with cycles in which a spotter was used [87]. However, cost calculation revealed that the longer cycle time is largely compensated by the lower personnel cost.

In the 2000s, the first camera systems were integrated by Eagle Inc. into their Yoder Claw and Mega Claw grapple carriages [21]. Today, almost all manufacturers of grapple carriages offer camera systems (Table 2). A distinction can be made between integrated [73, 83, 84] and bolt-on camera systems $[79,80]$. Bolt-on types can be retrofitted to any carriage, including mechanical grapple carriages [88]. All camera systems are usually battery operated and must be recharged typically after 2 to 3 days of operation. However, one manufacturer offers a camera system whereby the battery is recharged via a circuit connected to the carriage's engine [83]. Connection to the video display placed in the yarder cab is realized with wireless technology, which can connect the yarder over distances of several hundred meters, e.g., $900 \mathrm{~m}$ in case of the Falcon HD grapple camera system [80]. The display mounted inside the cabin provides the yarder operator with a birds-eye view of the cutover below the carriage. Carriage-integrated or add-on LED lighting systems, e.g., the Falcon Skylight [81], are available for further enhancement of vision. For operation under particularly poor visibility conditions, for example, mist, rain, twilight, or nighttime, camera systems with infrared capability are available [77, 80, 82, 83]. Night-time yarding has already been practiced by some entrepreneurs in the past, and an investigation in 2014 showed that nighttime productivity did not drop below daytime levels for bunched trees [89]. If $70 \%$ of the daytime productivity level can be attained during night-time operation in the long run, the potential for improving profitability was calculated at between 16 and $35 \%$. The authors concluded that night-time operation could increase production and profitability but pointed out that uptake of the practice may be hampered by specific night-time challenges (line shifts, maintenance and repair, transport logistics), as well as crew culture. The use of carriage-mounted cameras in operations involving chokers for automatic detection of choker setters in the danger zone using remote sensing image filtering techniques presents a further application case [90].

For faster outhaul and for enhanced and safer operation of grapple carriages during load pick-up, specific tools have been developed: T-Mar Industries offers the "Distance Marker," which displays the distance of the carriage from the yarder via a "line counter" (i.e., a sensor detecting yarder drum movement), and allows the yarder operator to save the previous loading point. This tool is available as an add-on and could be used with a variety of carriage types [79]. A similar functionality is integrated in the DC Falcon Claw carriage system, this time based on a GPS-based solution [82, 91].

In the past, grapple yarding was restricted to running or live skyline systems where the operating ropes could be lowered to the ground to pick up the load. Recently, Teleforest has presented a self-propelled carriage for standing skyline systems [74], for which a remote-controlled, battery-powered rotary grapple equipped with cameras is now available (Table 2) [73]. However, like conventional grapple carriages, this system is limited to single-span setups. Only in 2019, two European manufacturers presented each a motorized grapple carriage that can be used with standing skyline systems in multiple-span setups. Differently to the Teleforest carriage, the whole carriage chassis, including rotator and grapple, is lowered to a maximum drop height of $30 \mathrm{~m}$ and $40 \mathrm{~m}$, respectively. Only the bar and the skyline sheaves remain on the skyline when the chassis is lowered to lift or drop the load. Lowering and lifting can be performed during carriage travel to speed up loading and unloading [73, $78,92]$.

The latest report for New Zealand's Steepland Harvesting Programme indicates that 142 New Zealand-made grapple carriages (Falcon Claw, Hawkeye, Alpine) have been sold, along with over 220 camera systems (CutoverCam, Falcon Grapple Camera, Hawkeye grapple camera) [93], as of June 2019. Success is further indicated by a landslide change in grapple carriage use in New Zealand cable logging operations: between 2012 and 2018, the proportion of grapple carriages has increased from 4 to 55\%, while yarder configurations involving the use of carriages with chokers dropped from 74 to 29\% [71]. The combination of winch-assisted, mechanized felling and grapple yarding has led to a $25 \%$ increase in the productivity of cable logging operations since 2013. The popularity of winch-assisted technology is also indicated by the establishment of two new manufacturers and a total sale of 270 machines since 2012. Finally, mechanization of steep terrain felling and extraction resulted in a $64 \%$ reduction of serious harm accidents since 2012, and less than 10 accidents per year are expected by 2025 [93].

\section{Conclusions}

"The only way to decrease the operational cost is to introduce new organization of work (planning), methods (techniques), or equipment" [94]. In cable yarding logging, the most significant developments during the last decade clearly belong to the two last categories. The availability 
of sophisticated machine components and of new information and communication technology allowed to realize step changes in the functionality of carriages and to turn them into technology platforms equipped with a variety of sensors (geospatial, camera technology) to provide higher levels of automation. Drivers for development clearly differ between regions: while the needs for low mass, versatility, energy efficiency, and environmental soundness have developed a market for energy-recuperating, slack-pulling, and double-hitch carriages in the central European market, changes in New Zealand and North America were driven by a focus on safety and productivity. To this end, carriage designer's focus shifted almost exclusively to grapple carriages, which allow operation without chokers setters on the ground, exposed to the most severe hazards. North American developments also included improved carriages capable of larger payloads to increase productivity and off-set the high operating cost. Further, the shift towards grapple carriages was facilitated by the availability of winch-assisted machines for felling on steep slopes, which optimized load size and presentation for grapple yarding. By integrating new technologies for attaining greater efficiency and automation, new carriage models are playing a major role in making cable yarding systems more cost-competitive, safer, and environmentally sound.

Funding Open access funding provided by University of Natural Resources and Life Sciences Vienna (BOKU). Open access funding provided by University of Natural Resources and Life Sciences Vienna (BOKU).

\section{Declarations}

Conflict of Interest Thomas Varch, Gernot Erber, Raffaele Spinelli, Rien Visser, Hunter Harrill, and Karl Stampfer declare that they have no conflict of interest.

Human and Animal Rights and Informed Consent This article does not contain any studies with human or animal subjects performed by any of the authors.

Open Access This article is licensed under a Creative Commons Attribution 4.0 International License, which permits use, sharing, adaptation, distribution and reproduction in any medium or format, as long as you give appropriate credit to the original author(s) and the source, provide a link to the Creative Commons licence, and indicate if changes were made. The images or other third party material in this article are included in the article's Creative Commons licence, unless indicated otherwise in a credit line to the material. If material is not included in the article's Creative Commons licence and your intended use is not permitted by statutory regulation or exceeds the permitted use, you will need to obtain permission directly from the copyright holder. To view a copy of this licence, visit http://creativecommons.org/licenses/by/4.0/.

\section{References}

Papers of particular interest, published recently, have been highlighted as:

- Of importance

$\bullet$ Of major importance

1. Merriam-Webster. Online-dictionary search result for "carriage" [Internet]. 2021. Available from: https://www.merriam-webster. com/dictionary/carriage. Accessed Mar 302021.

2. Mifflin RW, Lyons HH. Glossary of Forest Engineering Terms. Portland (OR), U.S.A.: USDA Forest Service, Pacific Northwest Forest and Range Experiment Station; 1979. 24 p.

3. Studier D, Binkley VW. Cable Logging Systems. Portland (OR), U.S.A.: USDA Forest Service, Pacific Northwest Forest and Range Experiment Station; 1974. 211 p.

4. Stokes BJ, Ashmore C, Rawlins CL, Sirois DL. Glossary of terms used in timber harvesting and forest engineering. New Orleans (LA), U.S.A.: USDA Forest Service, Southern Forest Experiment Station; 1989. General technical report SO-73. 35 p.

5. Stampfer K. Rückung im Seilgelände [Extraction in steep terrain]. Vienna, Austria: University of Natural Resources and Life Sciences Vienna (BOKU); 2020. Unpublished lecture notes from lecture 915186: Forstliches Ingenieurswesen [Forest Engineering]. 62 p.

6. Magagnotti N, Kanzian C, Schulmeyer F, Spinelli R. Good practice guidelines. A new guide for work studies in forestry. Int J For Eng. 2013;24:249-53.

7. FAO. Cable logging systems. Rome, Italy: FAO; 1981. Forestry Paper $\mathrm{N}^{\circ} 24.109$ p.

8. Studier D. Carriages for skylines. Corvallis (OR), U.S.A.: Oregon State University, Forest Research Laboratory; 1993. Research Contribution 3.21 p.

9. Palmer W, Robinson P. The use of motorised slackpulling and Skycar carriages in cable operations. New Zealand Logging Industry Research Organisation; 1998. LIRO Technical Note $45.4 \mathrm{p}$.

10. Kellogg L, Bettinger P, Edwards R. A comparison of logging planning, felling and skyline yarding cost between clearcutting and five group-selection harvesting methods. W J Appl For. 1996;11(3):90-6. https://doi.org/10.1093/wjaf/11.3.90.

11. Marchi E, Picchio R, Spinelli R, Verani S, Venanzi R, Certini G. Environmental impact assessment of different logging methods in pine forests thinning. Ecol Eng. 2014;70:429-36. https://doi.org/10.1016/j.ecoleng.2014.06.019.

12. Hippoliti G. Le utilizzazioni forestali [Forest utilization]. Florence, Italy: CUSL; 1990. $111 \mathrm{p}$

13. Rajala RA. The forest as factory: technological change and worker control in the West Coast logging industry, 1880-1930. Labour / Le Travail. 1993;32:73-104.

14. Heinimann HR, Stampfer K, Loschek J, Caminada L. Perspectives on Central European cable yarding systems. In: Proceedings of International Mountain Logging and 11th Pacific Northwest Skyline Symposium; Seattle (WA), U.S.A; 2001. 9 p.

15. Christensen JA. Description of remote control cable yarding systems and an evaluation of the Forestral remote control grapple yarding system. MS Thesis. University of Montana, Missoula (MT, U.S.A.); 1978. 62 p.

16. Visser R, Harill H. Cable yarding in North America and New Zealand: a review of developments and practices. Cro J For Eng. 2017;38(2):209-17 (This paper provides a comprehensive overview of development and practices in cable logging 
in North America and New Zealand and outlines how steep slope harvesting may evolve in the future).

17.•• Harrill H, Visser R, Raymond K. New Zealand cable logging 2008-2018: a period of change. Curr For Rep. 2019;5:11423. https://doi.org/10.1007/s40725-019-00092-5 (This paper describes in detail the motives, process and result of the system change towards increased mechanization in steep slope harvesting during the last decade in New Zealand).

18 Erber G, Spinelli R. Timber extraction by cable yarding on flat and wet terrain: a survey of cable yarder manufacturer's experience. Silva Fenn. 2020;54(2):10211. https://doi.org/10.14214/ sf. 10211.

19. Abbas D, Di Fulvio F, Spinelli R. European and United States perspectives on forest operations in environmentally sensitive areas. Scand J For Res. 2018;33(2):188-201. https://doi.org/ $10.1080 / 02827581.2017 .1338355$.

20. Spinelli R, Magagnotti N, Jessup E, Soucy M. Perspectives and challenges of logging enterprises in the Italian Alps. For Pol Econ. 2017;80:44-51. https://doi.org/10.1016/j.forpol.2017.03. 006.

21. Evanson T. International grapple/carriage developments: a review of the literature. Rotorua, New Zealand: Future Forests Research; 2011a. Harvesting Technical Note HTN05-11. 5 p.

22. Spinelli R, Marchi E, Visser R, Harrill H, Gallo R, Cambi M, Neri F, Lombardini C, Magagnotti N. The effect of carriage type on yarding productivity and cost. Int J For Eng. 2017;28(1):34 41. https://doi.org/10.1080/14942119.2016.1267970.

23. Schönemann B, Henze R, Küçükay F, Kudritzki D. Auswirkungen der Rekuperation auf die Fahrdynamik [Effects of recuperation on driving dynamics]. ATZ Automobiltech Z. 2013;115:520-7. https://doi.org/10.1007/s35148-013-0149-5.

24. Reif K, Noreikat KE, Borgeest K. Kraftfahrzeug-Hybridantriebe [Automotive hybrid drives]. 1st ed. Wiesbaden, Germany: Springer Vieweg+Teubner; 2012. 354 p.

25. De Novellis L, Sorniotti A, Gruber P, Shead L, Ivanov V, Hoepping $\mathrm{K}$. Torque vectoring for electric vehicles with individually controlled motors: state-of-the-art and future developments. World Electr Veh J. 2012;5(2):617-28. https://doi.org/10.3390/ wevj5020617.

26. Babiel G. Elektrische Antriebe in der Fahrzeugtechnik [Electric drives in automotive engineering]. 3rd ed. Wiesbaden, Germany: Springer Vieweg+Teubner; 2014. 205 p.

27. Trzesniowski M. Rennwagentechnik - Grundlagen, Konstruktion, Komponenten, Systeme [Race car technology - fundamentals, design, components, systems]. 4th ed. Wiesbaden, Germany: Springer Vieweg+Teubner; 2014. 1046 p.

28. Nimz R. Seikrantechnik bei der KWF-Tagung [Cable yarding technology at the KWF-meeting]. Forst \& Technik. 2012;10:20-4.

29. Prysis - Prysis GmbH. Prisys company history [Internet]. 2021. Available from: https://www.prisys.at/historie.html. Accessed 30 Mar 2021.

30. Fehrle M. Forstmaschinen - Seilgeräte-Neuheiten auf der Austrofoma [Forest machinery - cable yarding innovations at Austrofoma] [Internet]. 2007. Available from: https://holz.fordaq. com/fordaq/news/Forstmaschinen_Seilger\%C3\%A4te_Austr ofoma_Holzernte_15756.html. Accessed Mar 312021.

31. Anonymous. Austrofoma: Gipfeltreffen in Sachen Seilkrantechnik [Austrofoma: Cable yarding summit] [Internet]. 2015. Available from: https://holz.fordaq.com/fordaq/news/Austrofoma Seilkran_Koller_Konrad_Mayr_Melnhof_44312.html. Accessed Mar 312021.

32. Anonymous. Interforst: Neues aus der Seilkrantechnik [Interforst: New developments in cable yarding technology] [Internet]. 2018. Available from: https://holz.fordaq.com/fordaq/news/Inter
forst_Seilkrananlagen_Laufwagen_59026.html. Accessed Mar 312021.

33. Koller - Koller Forsttechnik GmbH. Complete product range 2019/2020 [Internet]. 2019a. Available from: https://www.kolle rgmbh.com/media/attachments/2019/10/01/komplettprogramm en_2019_v07_web.pdf. Accessed 30 Mar 2021.

34. Koller - Koller Forsttechnik GmbH. Flyer ECKO FLEX [Internet]. 2019b. Available from: https://www.kollergmbh.com/ media/attachments/2020/11/12/flyer_a4_ecko_flex_de_web. pdf. Accessed 30 Mar 2021.

35. Konrad - Konrad Forsttechnik GmbH. EL30-1/EL50-1 manual. Preitenegg, Austria: Konrad Forsttechnik GmbH; 2019. 134 p.

36. Konrad - Konrad Forsttechnik GmbH. E-Liner product range [Internet]. 2021. Available from: https://www.forsttechnik.at/ products/carriage-systems/e-liner. Accessed 30 Mar 2021.

37. Mayr-Melnhof - Mayr-Melnhof Forsttechnik GmbH. Sherpa UE carriage description [Internet]. 2018. Available from: http:// www.mm-forsttechnik.at/_files/MM-SHERPA_UE_2.pdf. Accessed 30 Mar 2021.

38. Prysis - Prysis GmbH. CableCar 30 manual. Bruck/Mur, Austria: Prisys GmbH; 2015. 117 p.

39. Hochleitner - Franz Hochleitner. Bergwald product range [Internet]. 2021. Available from: https://www.franzhochleitner.com/ produkte.html?aid=0\#bergwald-laufwagen_anker. Accessed 30 Mar 2021.

40. Greifenberg - Greifenberg Teleferiche SAS. Ht 30 carriage product description. [Internet]. 2021. Available from: https://www. greifenberg.it/ht30.html. Accessed 30 Mar 2021.

41. Schilter - Schilter Seilbahn- und Metallbau GmbH. SE 4000 carriage product description [Internet]. 2021. Available from: https://www.schilter-seilbahnen.ch/home/maschinenbau-undforst/elektro-ausspuler/. 2021. Accessed 30 Mar 2021.

42 Korthauer R. Handbuch Lithium-Ionen-Batterie [Handbook for lithium-ion batteries]. Berlin-Heidelberg, Germany: Springer Vieweg; 2013. $436 \mathrm{p}$.

43 Schnabel P. Elektronik-Fibel: Grundlagen, Messtechnik, Bauelemente, Schaltungstechnik, Digitaltechnik [Electronics guide: fundamentals, measurement technology, components, circuit technology, digital technology]. 7th ed. Ludwigsburg, Germany: Schnabel; 2017. 334 p.

44 Plaßmann W, Schulz D, Döring P. Handbuch Elektrotechnik [Electrical engineering handbook]. 5th ed. Wiesbaden, Germany: Springer Vieweg+Teubner; 2009. 1143 p.

45 Böhmer E, Engelhardt D, Oberschelp W. Elemente der angewandten Elektronik. 16th ed. Wiesbaden, Germany: Springer Vieweg+Teubner; 2010. 506 p.

46. Guetif A. Klassifizierung von Batterien und Super-Kondensatoren als Energiespeicher [Classification of batteries and supercapacitors for energy storage]. In: Braunschweig, Germany: Technical University of Braunschweig. Drives and Trains: Annual Report of the Institute for Electrical Machines; 2006. p. $56-65$.

47 Heuck K, Dettmann KD, Schulz D. Elektrische Energieversorgung [Electrical power supply]. 9th ed. Wiesbaden, Germany: Springer Vieweg; 2013. 783 p.

48 Breuer B, Bill K. Bremsenhandbuch - Grundlagen, Komponenten, Systeme, Fahrdynamik [Brake handbook - fundamentals, components, systems, vehicle dynamics]. 5th ed. Wiesbaden, Germany: Springer Vieweg; 2017. 688 p.

49. DGVU - Deutsche Gesetzliche Unfallversicherung e. V. Hydropneumatische Druckspeicher [Hydropneumatic accumulators]. Berlin, Germany: Deutsche Gesetzliche Unfallversicherung e. V - Fachbereich Holz und Metall; 2019. FBHM-046. 15 p.

50. Puddu P, Paderi M. Hydro-pneumatic accumulators for vehicles kinetic energy storage: influence of gas compressibility and 
thermal losses on storage capability. Energy. 2012;57:326-35. https://doi.org/10.1016/j.energy.2013.04.072.

51. Franke P. Contribution to the energy efficiency and environmental compatibility of cranes for inland waterway/ feeder ship handling. Logist. J. 2014;8. https://doi.org/10.2195/lj_Rev_franke_ en_201407_01.

52.•• Varch T, Erber G, Spinelli R, Magagnotti N, Stampfer K. Productivity, fuel consumption and cost in whole tree cable yarding: conventional diesel carriage versus electrical energy-recuperating carriage. Int J For Eng. 2020. https://doi.org/10.1080/14942 119.2020.1848178 (This paper was the first to investigate energy-recuperating carriages and their impact on productivity and fuel consumption, for which a sophisticated machine data-based approach was employed).

53. Vorraber M. Produktivität bei der Holzrückung mit dem Mastseilgerät Koller K 307C-H und dem energierückgewinnenden Laufwagen ESK 2.0. [Productivity of timber extraction with the tower yarder Koller K 307C-H and the energy-recuperating carriage ESK 2.0]. MS Thesis. Vienna (Austria): University of Natural Resources and Life Sciences Vienna; 2020. 47 p.

54. Valente C, Spinelli R, Hillring BG. LCA of environmental and socio-economic impacts related to wood energy production in alpine conditions: Valle di Fiemme (Italy). J Clean Prod. 2011;19(17-18):1931-8. https://doi.org/10.1016/j.jclepro.2011. 06.026.

55. Drăgan IC, Bora L, Cerchez G, Comănescu A, Stan I. Funiculare forestiere [Cable yarders]. Bucharest, Romania: Ceres Publishing House; 1971.

56. Giordano G. Installazione e messa in funzione delle teleferiche. Rome, Italy: Consiglio Nazionale delle Ricerche; 1967. CSP IX: p. 196-243

57.•• Spinelli R, Magagnotti N, Cosola G, Grigolato S, Marchi L, Proto AR, Labelle ER, Visser R, Erber G. Skyline tension and dynamic loading for cable yarding comparing conventional single-hitch versus horizontal double-hitch suspension carriages. Int J For Eng. 2021a. https://doi.org/10.1080/14942119.2021. 1909322. (This paper investigated the effect of single-hitch and a double-hitch carriage employment on skyline tension and its implications for rigging requirements and work safety).

58. Spinelli R, Magagnotti N, Cosola G, Labelle ER, Visser R, Erber $\mathrm{G}$. The effect of yarding technique on yarding productivity and cost: conventional single-hitch suspension vs. horizontal double-hitch suspension. Cro J For Eng. 2021b;42(3):369-80 (This paper investigated the effect of single-hitch and a doublehitch carriage employment on productivity and cost of a cable yarding operation).

59. Spinelli R, Magagnotti N, Facchinetti D. Logging companies in the European mountains: an example from the Italian Alps. Int J For Eng. 2013;24(2):109-20. https://doi.org/10.1080/14942119. 2013.838376.

60. Spinelli R, Visser R, Björheden R, Röser D. Recovering energy biomass in conventional forest operations: a review of integrated harvesting systems. Curr For Rep. 2019;5:90-100. https://doi. org/10.1007/s40725-019-00089-0.

61. Raymond K. Alpine shovel yarder in New Zealand. Rotorua, New Zealand: Future Forests Research Ltd.; 2018. Harvesting Technology Watch HTW-018. 5 p.

62. MPI. 2019 Forestry labour requirements survey. Wellington, New Zealand: Ministry for Primary Industries; 2019. 19 p.

63. Raymond K. Steepland harvesting programme - Final programme report. Rotorua, New Zealand: Forest Growers Research Ltd. 2017. Report H032. 22 p.

64. Milliken P. Steep slope logging conference: Vancouver B.C. March 2016. Rotorua, New Zealand: Future Forest Research Ltd. 2016. Report H026. 20 p.
65.• Holzfeind T, Visser R, Chung W, Holzleitner F, Erber G. Development and benefits of winch-assist harvesting. Curr For Rep. 2020;6:201-9. https://doi.org/10.1007/s40725-020-00121-8 (This paper provides a comprehensive review of winchassisted harvesting system development and its impact on productivity, work safety and environment in steep slope harvesting).

66. Evanson T. Improved grapple control - the Alpine grapple. Rotorua, New Zealand: Future Forests Research Ltd.; 2013. Harvesting Technical Note HTN05-08. 5 p.

67. McFadzean S, Visser R. Falcon Forestry Claw grapple: productivity and ergonomics. Rotorua, New Zealand: Future Forests Research Ltd.; 2013. Harvesting Technical Note HTN05-08. 5 p.

68. Engelbrecht R, McEwan A, Spinelli R. A robust productivity model for grapple yarding in fast-growing tree plantations. Forests. 2017;8:396. https://doi.org/10.3390/f8100396.

69. Snyman J. Scorpion grapple carriage. Concept appraisal. Rotorua, New Zealand: Future Forest Research Ltd. 2014. Report H016. 24 p.

70. Ybarra P. Grapple carriage. US 2020/0071135 A1 (Patent). 2020. $12 \mathrm{p}$.

71. Harrill H, Visser R. Survey of yarders and rigging configurations: 2018. Rotorua: Future Forests Research Ltd.; 2018. Harvesting Technical Note HTN10-04. 9 p.

72. Evanson T. Development of an improved carriage control system: a feasibility study. Rotorua, New Zealand: Future Forests Research Ltd.; 2011b. Report H005. 19 p.

73. Anonymous. Tech Review - Grapple carriages [Internet]. 2019a. Available from: https://forestnet.com/TWissues/2019-septe mber-october/tech-review.php. Accessed Apr 72021.

74. Amishev D. Telecarrier cable yarding system from Teleforest Inc. Rotorua: Future Forests Research Ltd.; 2012. Harvesting Technology Watch HTW-009. 7

75. Acme - Acme Manufacturing Inc. Carriages [Internet]. 2021. Available from: https://www.acmecarriages.com/carriages/carri ages.html. Accessed Apr 152021.

76. Eagle - Eagle Carriage \& Machine Inc. Services [Internet]. Available from: https://eaglecarriage.com/services/. Accessed Apr 152021.

77. Alpine - Alpine Logging Equipment Ltd. Alpine Grapple - Models AGC-2/AGC-3 [Internet]. 2021. Available from: https://integralequipment.ca/brochures/AGC-2-3_041719.pdf. Accessed 12 Apr 2021.

78. Koller - Koller Forsttechnik GmbH. Flyer GSK-4 [Internet]. 2021. Available from: https://www.kollergmbh.com/images/ laufwagen/gsk4/gsk4_1seitig_de_web.pdf. Accessed Apr 7 2021.

79. T-Mar - T-Mar Industries Ltd. Yarding grapple and accessories: Grapple cameras - Distance markers [Internet]. 2018. https:// www.tmarequipment.com/site/assets/files/1055/t-mar-yardinggrapple-brochure-2018.pdf. Accessed 12 Apr 2021.

80. DC - DC Equipment Ltd. Falcon HD grapple camera system Information and specifications [Internet]. 2021a. Available from: https://f.hubspotusercontent20.net/hubfs/2821671/DC-NZ-FFEGrappleCam-April2021-Digital.pdf. Accessed 12 Apr 2021.

81. DC - DC Equipment Ltd. Falcon Skylight [Internet]. 2021b. Available from: https://f.hubspotusercontent20.net/hubfs/28216 71/DC_Forestry_Equipment_August2020/pdf/FFE-SkylightBrochure-Low-Res.pdf. Accessed 12 Apr 2021.

82. DC - DC Equipment Ltd. Falcon Claw 1750 - Information and specifications [Internet]. 2020. Available from: https://f.hubsp otusercontent20.net/hubfs/2821671/DC-NZ-FFEClaw-DIGIT AL-JAN2020.pdf. Accessed 12 Apr 2021. 
83. EMS - Electrical \& Machinery Services Ltd. Hawkeye [Internet]. 2021. Available from: http://emsnewzealand.co.nz/hawke ye/. Accessed 12 Apr 2021.

84. Summit - Summit Attachments Ltd. Summit grapple carriages [Internet]. 2021. Available from: https://www.summitattachmen ts.com/summit-grapple-carriage/. Accessed 12 Apr 2021.

85. MacMillan Bloedel. MB's video yarding system increases productivity. Logging and Sawmilling Journal. 1983;14(2).

86. Evanson T. Hauler Vision System. Rotorua, New Zealand: Future Forests Research Ltd.; 2012. Harvesting Technical Note HTN05-03. 5 p.

87. Hill S. Production trials of the CutoverCam. Rotorua: Forest Growers Research Ltd.; 2017. Harvesting Technical Note HTN09-09. 6 p.

88. Visser R, Raymond K, Harrill H. Developing fully mechanised steep terrain harvesting operations. In: Proceedings of the $47^{\text {th }}$ International Symposium on Forestry Mechanization; Gerardmer, France. 2014. 8 p.

89. Hill S. Logging after dark with an Alpine Grapple Carriage fitted with lights. Rotorua: Future Forests Research Ltd.; 2014. Harvesting Technical Note HTN07-02. 6 p.

90. Keefe R, Eitel J. Application of carriage-mounted agricultural cameras to improve safety in cable logging operations. In:
Proceedings of the 36th Council on Forest Engineering; Missoula (MT), U.S.A. 2013. 6 p.

91. Milne S. Falcon Forestry Claw motorised grapple carriage: solving performance limitations. Rotorua, New Zealand: Future Forests Research Ltd.; 2012. Report H009. 17 p.

92. Anonymous. Austrofoma: Neuheiten aus der Seilkrantechnik [Austrofoma: Innovations in cable yarding technology] [Internet]. 2019b. https://holz.fordaq.com/fordaq/news/Austrofoma_ Seilkrantechnik_66049.html. Accessed Apr 72021.

93. Raymond K. Steepland harvesting programme - Post-programme report 2019. Rotorua, New Zealand: Forest Growers Research Ltd. 2019. Report H043. 22 p.

94. Samset I. Winch and cable systems. Dordrecht, The Netherlands: Martinus Nijhoff/Dr. W. Junk Publishers; 1985.

Publisher's Note Springer Nature remains neutral with regard to jurisdictional claims in published maps and institutional affiliations. 